\title{
Nutrient excess and altered mitochondrial proteome and function contribute to neurodegeneration in diabetes
}

\author{
Subir K. Roy Chowdhury ${ }^{a,{ }^{*}}$, Rick T. Dobrowsky ${ }^{b}$, and Paul Fernyhougha,c \\ aDivision of Neurodegenerative Disorders, St Boniface Hospital Research Centre, Winnipeg, MB, \\ Canada R2H $2 \mathrm{~A} 6$ \\ bDepartment of Pharmacology \& Toxicology, University of Kansas, Lawrence, KS 660 45, USA \\ 'Department of Pharmacology \& Therapeutics, University of Manitoba, Winnipeg, MB, Canada \\ R3E 0T6
}

\begin{abstract}
Diabetic neuropathy is a major complication of diabetes that results in the progressive deterioration of the sensory nervous system. Mitochondrial dysfunction has been proposed to play an important role in the pathogenesis of the neurodegeneration observed in diabetic neuropathy. Our recent work has shown that mitochondrial dysfunction occurs in dorsal root ganglia (DRG) sensory neurons in streptozotocin (STZ) induced diabetic rodents. In neurons, the nutrient excess associated with prolonged diabetes may trigger a switching off of AMP kinase (AMPK) and/or silent information regulator T1 (SIRT1) signaling leading to impaired peroxisome proliferatoractivated receptor $\gamma$ coactivator-1a (PGC-1a expression/activity and diminished mitochondrial activity. This review briefly summarizes the alterations of mitochondrial function and proteome in sensory neurons of STZ-diabetic rodents. We also discuss the possible involvement of AMPK/ SIRT/PGC-1a pathway in other diabetic models and different tissues affected by diabetes.
\end{abstract}

\section{Keywords \\ Mitochondrial respiratory chain; Diabetic neuropathy; Dorsal root ganglia; PGC-1a; AMPK; SIRT}

\section{Introduction}

\begin{abstract}
Diabetes may lead to a number of complications that affect various tissues: heart and skeletal muscle, retina, secretory glands, kidneys, and peripheral nerves. Chronic metabolic stress induced by hyperglycemia resulting from either low insulin production in type 1 diabetes or decreased peripheral sensitivity to insulin in type 2 diabetes affects cellular homeostasis in virtually all cell types. At the same time the cellular pathophysiology of diabetes-induced impairments remain controversial. Diabetic neuropathy most often develops in the midst of other complications observed in diabetes. The putative pathogenesis of diabetic neuropathy includes increased polyol pathway activity leading to the
\end{abstract}

\footnotetext{
(C) 2011 Elsevier B.V. and Mitochondria Research Society. All rights reserved.

*Corresponding author: Subir K. Roy Chowdhury, St. Boniface Hospital Research Centre, R4023-1 - 351 Tache Ave, Winnipeg, MB R2H 2A6, Canada. Tel: (204) 235 3574; Fax: (204) 237 4092; skr_chowdhury@yahoo.ca.

Publisher's Disclaimer: This is a PDF file of an unedited manuscript that has been accepted for publication. As a service to our customers we are providing this early version of the manuscript. The manuscript will undergo copyediting, typesetting, and review of the resulting proof before it is published in its final citable form. Please note that during the production process errors may be discovered which could affect the content, and all legal disclaimers that apply to the journal pertain.
} 
accumulation of sorbitol and fructose (Oates, 2002, 2008), advanced glycation-end products produced by non-enzymatic glycation of proteins (Duran-Jimenez et al., 2009; Thornalley, 2002), inappropriate activation of protein kinase C (Eichberg, 2002) and reduced neurotrophic support - maintenance of normal phenotype of neurons is impaired due to diabetes-induced loss of neurotrophic support by insulin, insulin-like growth factors (IGF-I, IGF-II), nerve growth factor (NGF) and neurotrophin-3 (NT-3) (Calcutt et al., 2008). Mitochondrial dysfunction occurs in a range of diabetic complications and given their central role in controlling the bioenergetic status of the cell, may be considered a prime trigger of nerve degeneration (Sivitz and Yorek, 2010). Our recent work has shown that mitochondrial dysfunction occurs in dorsal root ganglia (DRG) sensory neurons in STZ (streptozotocin)-diabetic mice and rats and is characterized by impaired electron transport complex activities, reduced rates of oxidative phosphorylation and aberrant physiology in axons (Akude et al., 2011; Chowdhury et al., 2010). Studies in muscle, liver and cardiac tissues have shown that the AMP kinase (AMPK), silent information regulator T1 (SIRT1) and peroxisome proliferator-activated receptor $\gamma$ coactivator-1a (PGC-1a) signaling axis senses the metabolic demands of cells and regulates mitochondrial function accordingly e.g. under nutrient starvation the pathway is activated to enhance ATP production (Feige and Auwerx, 2007; Puigserver et al., 1998). SIRT1 and 3 are deacetylases that alter the functions of an array of proteins including enzymes and histones and thus have far-reaching effects on global gene expression. PGC-1a is a primary target of AMPK and SIRT1 that controls the expression of a family of proteins required for mitochondrial function, biogenesis and regeneration. Our general hypothesis is that in neurons, prolonged diabetes results in nutrient excess and polyol pathway-mediated diminishment of the NAD ${ }^{+} / \mathrm{NADH}$ ratio. This results in a switching off of AMPK and/or SIRT isoforms leading to impaired PGC-1a expression/activity and a subsequent decrease in mitochondrial respiratory enzyme chain activities.

\section{Clinical impact and socio-economic burden of diabetes and diabetic neuropathy}

Diabetes causes about $5 \%$ of all deaths globally each year. It has received an increased attention in recent decades due to its high prevalence and enormous economic burden on our society. According to the Canadian Diabetic Association, an estimated 285 million people world-wide have diabetes. With a further 7 million people developing diabetes each year, this number is expected to hit 438 million by 2030

(http://www.diabetes.ca/diabetes-and-you/what/prevalence/). Data from 1997, published in National Diabetes Fact Sheet, revealed that in the USA, 23.6 million children and adults had diabetes and that another 57 million were in a pre-diabetic condition. Of those, about 9095\% have non-insulin-dependent diabetes mellitus (Type 2 diabetes) and 5-10\% have insulin-dependent diabetes mellitus (Type 1 diabetes). In the USA, approximately $\$ 116$ billion was spent in 2007 to cover direct health service costs for treatment of diabetic complications that include retinopathy, nephropathy, heart disease, and neuropathy. The indirect costs were $\$ 58$ billion due to disability, work loss, and premature mortality. About $60 \%$ to $70 \%$ people with diabetes have mild to severe forms of nervous system damage. The incidence of sensory and autonomic neuropathies in diabetic patients leads to incapacitating pain, digestive abnormalities, erectile dysfunction, heart arrhythmia, sensory loss, foot ulceration (up to 2 million Americans have this complaint), infection, gangrene and poor wound healing. In the USA in 1998, approximately \$15 billion of heath service expenditure was associated with the neurological complications (sensory and autonomic neuropathy and blindness). The end result is often lower extremity amputation which accounts for approximately 80,000 cases each year in the USA. There is no effective therapy, only palliative treatment is available at the present time. These alarming figures are estimated to 
rise by approximately 5 -fold over the next 10 years due to the epidemic in obesity and the associated increase in incidence and earlier time of onset of Type 2 diabetes ( from American Diabetes Association web site: http://www.diabetes.org/diabetes-basics/diabetes-statistics/).

\section{Neurodegenerative features of diabetic sensory neuropathy}

Diabetic neuropathy, the most common form of peripheral neuropathies, occurs with similar functional, morphological, and metabolic changes documented in both human and animal models of Type 1 and 2 diabetes. The features of this disease are associated with a reduction of motor and sensory nerve conduction velocity and a wide range of structural changes in peripheral nerves that includes endoneurial microangiopathy, abnormal Schwann cell pathology, axonal degeneration, paranodal demyelination and loss of myelinated and unmyelinated fibers - the latter due to a dying-back of distal axons that presents clinically as reduced epidermal nerve fibre density (Estrella et al., 2008; Malik et al., 2005; Mizisin et al., 2007; Mizisin et al., 2002; Sima, 2004; Yagihashi, 1997). The neurodegeneration is most profound in the longest axons of neurons, and defective axon regeneration impedes tissue reinnervation (Polydefkis et al., 2004). Apoptosis-dependent loss of sensory or sympathetic neuron perikarya has not been found in diabetic humans or animals (Kamiya et al., 2006; Kamiya et al., 2005; Schmidt et al., 1997a; Schmidt et al., 1997b; Sidenius and Jakobsen, 1980), although loss of small unmyelinated neurons does occur in long-term mouse models of diabetes (Kennedy and Zochodne, 2005). The distal dying-back and formation of axonal dystrophy (with swellings) of axons are critical pathological features (Kennedy et al., 1996; Polydefkis et al., 2004; Schmidt et al., 1997b) and mimic axonal pruning and degeneration observed in the CNS and PNS in other pathological states (Nja and Purves, 1978).

\section{Mitochondria and diabetic neuropathy}

Mitochondrial dysfunction has been implicated in the pathophysiology of diabetic complications. The muscle, heart, kidney, and nerves all demonstrate abnormalities of mitochondrial structure and function in both clinical and animal models of diabetes. Mutation or loss of proteins associated with mitochondrial function can lead to neuropathy that mimics that seen in diabetes, for example, loss of function of mitofusin-2 or bcl-w results in a length-dependent sensory fiber degeneration (Baloh et al., 2007; Courchesne et al., 2011; Pazyra-Murphy et al., 2009). Studies on mitochondrial physiology in diabetic neuropathy lag behind those in other diabetic complications, such as in muscle, cardiomyopathy and nephropathy. Table 1 summarizes findings in an array of animal models, and in humans, in Type 1 and 2 diabetes with respect to analysis of functioning of the mitochondrial respiratory chain. In general, mitochondrial-based electron transport functions are diminished.

\section{1. Altered mitochondrial oxidative phosphorylation and proteome in diabetic sensory neuropathy}

Our recent published results on mitochondrial function in DRG of STZ-diabetic rats are in general agreement with those findings described in muscle, heart and kidney (Akude et al., 2011; Chowdhury et al., 2010; Zherebitskaya et al., 2009). Rates of coupled respiration with pyruvate + malate $(\mathrm{P}+\mathrm{M}$; full respiratory chain) and with ascorbate + TMPD (Asc + TMPD; Complex IV) in lumbar DRG were unchanged up to 12 weeks of diabetes (Chowdhury et al., 2010). By 22 weeks of diabetes, respiration with $\mathrm{P}+\mathrm{M}$ was significantly decreased by $31-44 \%$ and with Asc + TMPD by $29-39 \%$ in STZ-diabetic rats compared to control. Attenuated mitochondrial respiratory activity of STZ-diabetic rats was significantly improved by insulin treatment (Fig. 1 taken from (Chowdhury et al., 2010)). Enzymatic activities of mitochondrial complexes I and IV and the Krebs cycle enzyme, citrate synthase, 
were decreased in mitochondria from DRG of 22 week STZ-diabetic rats compared to control (Fig. 2 taken from (Chowdhury et al., 2010)). The diabetes-induced factors causing reduced rates of respiratory complex activities remain poorly understood, however, investigators have begun to use proteomic and gene array techniques to identify alterations in gene expression that presumably underpin such changes in mitochondrial physiology (for example, see (Bugger et al., 2009)). The stable isotope labeling with amino acids in cell culture (SILAC)-based quantitative proteomics analysis of mitochondrial protein expression in the mitochondria from 22 week STZ-diabetic rats by our group revealed that diabetes altered the levels of an array of proteins (mitochondrial complexes - Complex I-V, tricarboxylic acid (TCA) cycle, oxidative stress, fatty acid utilization) associated with the mitochondrial function (Table 2 taken from (Akude et al., 2011)). Reduced expression of oxidative phosphorylation genes have been found in Type 2 diabetes (Patti et al., 2003), and decreased expression of the transcriptional regulator, nuclear respiratory factor 1 (NRF-1) and the translational co-activator, PGC-1a were observed in pre-diabetic and diabetic muscle (Mootha et al., 2003). Our results showing reduced expression of NADH dehydrogenase Fe-S protein 3 (NDUFS3) and subunit IV of cytochrome $c$ oxidase (COX IV) in lumbar DRG of STZ-induced diabetic mice (Fig. 3) and rats (Chowdhury et al., 2010) are consistent with these findings and support the premise that reduced activity of the mitochondrial respiratory chain could result from a proteome alteration leading to reduced expression/activity of a range of mitochondrial components. We have proposed that this broad spectrum of protein expression changes underpin the altered activity and physiology of the mitochondria in neurons in diabetes resulting in impaired bioenergetics in axons and subsequent degeneration.

\subsection{Oxidative stress in diabetic neuropathy}

Oxidative stress has been implicated in the pathological process inducing nerve damage in diabetes (Obrosova, 2002; Vincent et al., 2004). Oxidative stress, possibly triggered by vascular abnormalities and associated microangiopathy in the nerve (Cameron et al., 2001; Malik et al., 2005), is a key pathological process inducing nerve damage in diabetes in humans and experimental models (Obrosova, 2002; Vincent et al., 2004). Diabetes-induced oxidative stress in sensory neurons and peripheral nerve is demonstrated by increased production of reactive oxygen species (ROS) (Coppey et al., 2003; Nishikawa et al., 2000b; Oltman et al., 2009; Russell et al., 2002), lipid peroxidation (Obrosova et al., 2002), protein nitrosylation (Obrosova et al., 2005a; Obrosova et al., 2005b), and reduced levels of reduced glutathione (Ho et al., 2006; Obrosova et al., 2002) and ascorbate (Obrosova et al., 2002). The neurodegenerative outcome is energy failure in the nerve, observed as a decrease in high energy intermediates (e.g. phosphocreatine) (Obrosova, 2002; Vincent et al., 2004), impaired axonal transport of proteins (Fernyhough and Schmidt, 2002) and sub-optimal ion pumping (Hall et al., 1995; Huang et al., 2002; Kruglikov et al., 2004). However, treatments with anti-oxidants such as $a$-lipoic acid, $\gamma$-linolenic acid and aldose reductase inhibitors have shown to prevent many indices of neuropathy in STZ-diabetic rats (Obrosova, 2002; Vincent et al., 2004; Yorek et al., 2004).

Elevated production of reactive oxygen species (ROS) and mitochondrial hyperpolarization are exhibited by cultured endothelial cells after a short period of exposure to high [glucose] that may drive excessive electron donation to the electron transport chain in mitochondria (Nishikawa et al., 2000b). Brownlee et al. have proposed that this mitochondrial-dependent process is a central mediator of oxidative stress in complications of diabetes (Nishikawa et al., 2000a; Nishikawa et al., 2000b). Studies in cultured embryonic sensory neurons have shown that high [glucose] induces toxicity through an apoptotic route involving a mitochondrial-dependent pathway (Vincent et al., 2004). But studies on adult sensory neurons from normal and STZ-diabetic rats indicate that adult neurons have different 
responses to high [glucose] compared with endothelial cells and embryonic neurons. Our work and studies by Wiley et al. have shown that in adult sensory neurons from STZdiabetic rats, the mitochondrial inner membrane potential is depolarized, not hyperpolarized as observed in endothelial cells exposed to high [glucose] (Huang et al., 2003; Huang et al., 2005; Srinivasan et al., 2000). In our recent study, impaired mitochondrial respiratory chain activity was not accompanied by increased ROS production in neuronal perikarya from STZ-diabetic rats (Chowdhury et al., 2010). However, we have recently found that ROS levels and protein adducts of 4-hydroxy-2-nonenal are elevated in the presence of high glucose concentration in axons of adult sensory neurons isolated from 3- to 5-month STZdiabetic rats, with the perikarya being unaffected (Zherebitskaya et al., 2009). These results suggest that mitochondrial function may differ between axons and perikarya or that oxidative stress in axons and other cells of the nerve trunk may derive from alternative sources. One of our studies also provides preliminary evidence that the sources of ROS in axons of diabetic neurons may, in part, derive from the polyol pathway. This pathway has been proposed as a source of ROS through a putative sorbitol accumulation-dependent NADPH oxidase route in previous studies (Ido et al., 2010; Oates, 2008). In agreement with this evidence, the specific sorbitol dehydrogenase inhibitor, SDI-158, blocked high [glucose]-dependent ROS production in the axons of diabetic neurons (Akude et al., 2011).

\section{AMPK/SIRT/PGC-1a pathway in neurons}

AMPK is a major metabolic sensor and master regulator of metabolic homeostasis (Hardie, 2007). SIRT1 plays an important role in metabolic function and longevity in mammals. Both AMPK and SIRT1 act in concert with the master regulator of mitochondrial biogenesis, PGC-1a to regulate energy homeostasis in response to environmental and nutritional stimuli (Hardie, 2007; Reznick and Shulman, 2006). Studies on this signaling axis in neurons remain remarkably limited. Resveratrol activates AMPK in cultured neurons (Dasgupta and Milbrandt, 2007) and in animal models of Huntington and Alzheimer's disease, PGC-1a and SIRT1 are protective (Kim et al., 2007; St-Pierre et al., 2006). In Type 1 diabetic rats, resveratrol improved indices of neuropathy (Kumar et al., 2007; Sharma et al., 2009).

\subsection{PGC-1 $\alpha$ and cell metabolism}

PGC-1a is a potent coactivator of a plethora of transcription factors impacting on wholebody energy expenditure, including myocyte enhancer factor-2, forkhead O-box (FOXO) transcription factors and nuclear receptors (e.g. PPARs and estrogen-related receptors) (Feige and Auwerx, 2007; Michael et al., 2001; Puigserver et al., 2003; Vega et al., 2000). By way of these varied interactions, PGC-1a coordinately regulates gluconeogenesis, glycolysis, lipogenesis, peroxisomal and mitochondrial fatty acid oxidation, and mitochondrial respiration efficiency. PGC-1a is mainly expressed in tissues with high energy oxidative capacity such as heart, skeletal muscle, liver, brown adipose tissue and brain, and is robustly induced in conditions requiring energy, e.g. cold, fasting and exercise (Puigserver et al., 1998). Over-expression of PGC-1a induces increased mitochondrial number and function (Lin et al., 2002). Conversely, deletion of PGC-1a results in abnormal glucose homeostasis and decreased mitochondrial function (Handschin et al., 2007). Decreased PGC-1a levels have been reported in skeletal muscle from insulin-resistant and Type 2 diabetic patients (Mootha et al., 2003; Patti et al., 2003; Richardson et al., 2005). PGC-1a activity is regulated by both its expression level and by posttranslational modifications involving acetylation and phosphorylation (Rodgers et al., 2008). Two proteins, SIRT1 and AMPK, play major roles in metabolic regulation and have recently been shown to impact on PGC-1a to transcriptionally regulate energy expenditure (Rodgers et al., 2008). 


\subsection{SIRT1 and the control of PGC-1 $\alpha$ activity}

SIRT1 is a cytoplasmic enzyme (SIRT3 is the mitochondrial form) that mediates NAD ${ }^{+}$dependent deacetylation of target substrates. SIRT1 acts as a sensor of $\mathrm{NAD}^{+}$levels that directly connects metabolic perturbations with transcriptional outputs; it was initially characterized as a histone deacetylase (Bao and Sack, 2010). High NAD + NADH ratios activate SIRT1, which can directly interact with and regulate the activity of transcription factors and co-regulators, including PGC-1a, PPAR- $\gamma$, p53 and the FOXO family of transcription factors (Nemoto et al., 2005; Rodgers et al., 2005). Deacetylation of PGC-1a increases its transcriptional activity and acetyltransferase enzymes have been demonstrated to inhibit PGC-1a activity by increasing its acetylation (Canto and Auwerx, 2009). SIRT1mediated regulation of PGC-1 $a$ activity may play a major role in the metabolic adaptations to energy metabolism in different tissues (Canto and Auwerx, 2010). Recent work shows high glucose can down-regulate SIRT1 expression in endothelial cells (Balestrieri et al., 2008 ) and the diabetic state lowers the $\mathrm{NAD}^{+} / \mathrm{NADH}$ ratio in retina and nerve (Ido et al., 2010; Li et al., 2004; Oates, 2008; Obrosova et al., 2006).

\subsection{AMPK and linking PGC-1 $\alpha$ activity to energy status}

AMPK is a multi-component Ser/Thr kinase activated by direct binding of AMP upon a rise in the cellular AMP/ATP ratio (Hardie, 2008). Once activated, AMPK switches on catabolic pathways to produce ATP while simultaneously shutting down energy-consuming anabolic processes. To perform these actions, AMPK quickly regulates metabolic enzymes through direct phosphorylation, but also has long-term effects at the transcriptional level to adapt gene expression to energy demands. Mice expressing a dominant-negative form of AMPK cannot increase mitochondrial biogenesis in response to energy deprivation in skeletal muscle (Zong et al., 2002). In mice overexpressing an activated form of the AMPK- $\gamma 3$ subunit, the expression of genes controlling lipid oxidation and mitochondrial activity are induced (Garcia-Roves et al., 2008). There is a strong overlap in genes that are transcriptionally regulated by AMPK and PGC-1a, suggesting that PGC-1a may be an important mediator of AMPK-induced gene expression (Feige and Auwerx, 2007). AMPK activation increases PGC-1a expression/phosphorylation and AMPK requires PGC-1a activity to modulate the expression of several key players in mitochondrial and glucose metabolism (Jager et al., 2007). There is also a positive feedback loop linking AMPK with SIRT1. SIRT1 elevates AMPK activity through deacetylation of LKB1, the upstream kinase which phosphorylates and activates AMPK (Lan et al., 2008), and AMPK enhances SIRT1 via elevation of $\mathrm{NAD}^{+}$(Bao and Sack, 2010). Finally, high glucose concentration and/or nutrient excess leads to down-regulation of AMPK activity in several cell types (da Silva Xavier et al., 2003; Mountjoy et al., 2007; Mountjoy and Rutter, 2007).

\subsection{Diabetes in mice down-regulates AMPK and PGC-1a}

In DRG from STZ-diabetic Swiss Webster mice, the expression of phosphorylated (PAMPK), and PGC-1a was decreased significantly by 8 wks (Fig. 4). The lowered activation status of the up-stream regulators of mitochondrial biogenesis, AMPK and PGC1-a correlated with the down-regulation of an array of mitochondrial proteins confirmed by Western blotting and proteomic analysis ((Akude et al., 2011) and Table 2). The most significant changes were decreased levels of mitochondrial enzyme components involved in oxidative phosphorylation (NDUFS3, COX IV), the Kreb's cycle enzyme (citrate synthase) and the oxidative stress scavenger (Mn-superoxide dismutase). In the cardiac system, diminished mitochondrial respiratory function caused by diabetes has also been identified by proteomics and gene array techniques (Bugger et al., 2008; Bugger et al., 2009). These broad changes in gene expression could be triggered by altered activity of key upstream regulators. In human skeletal muscle in Type 2 diabetes, the transcriptional regulator, NRF-1 and the transcriptional co-activator, PGC-1a were downregulated and corresponded with 
reduced expression of proteins that regulate cellular energy metabolism, including mitochondrial biogenesis and oxidative phosphorylation (Mootha et al., 2003; Patti et al., 2003). In addition, a recent report by Iwabu et al, clarified that adiponectin (anti-diabetic adipokine) and adiponectin receptor 1 regulate PGC-1a and mitochondria through $\mathrm{Ca}^{2+}$ and AMPK/SIRT1 (Iwabu et al., 2010). In fact, our preliminary data identified a significant reduction in activity of SIRT3 in DRG of type 1 diabetic rodents (data not shown). Our results in STZ-diabetic mice presented in Figs. 3 and 4 along with the decreased level of SIRT3 support a causal link between AMPK/SIRT/PGC-1a pathway and mitochondrial dysfunction in sensory neuropathy developed under diabetic conditions.

\section{Possible mechanism of induction of diabetic sensory neuropathy}

Sensory neurons do not exhibit insulin-dependent glucose uptake, thus hyperglycemia leads to nutrient excess and so the AMPK/SIRT/PGC-1a pathway is deactivated. The scheme in Fig. 5 shows that this results in a general down-regulation of mitochondrial oxidative capacity and increased susceptibility to cell stress. This process is akin to the 'Crabtree effect' since ATP resources are considered by the cell body to be adequate and so oxidative phosphorylation can be deactivated and anaerobic metabolism, e.g. glycolysis, can suffice. In highly polarized cells such as neurons this may create a unique metabolic problem in specific cellular compartments (e.g. the high energy requiring distal axon). In addition, elevated glucose flux through the polyol pathway leads to high rates of sorbitol oxidation and diminishment in the $\mathrm{NAD}^{+} / \mathrm{NADH}$ ratio (in the cytoplasm and mitochondria). This will effectively lower $\mathrm{NAD}^{+}$levels and so reduce SIRT1/3 activity. In addition, the raised NADH levels will enhance oxidative stress, in part, through elevated NADPH oxidase as proposed by Williamson et al (Ido et al., 2010). Our recent paper provides pharmacological evidence that sorbitol oxidation contributes to oxidative stress in axons of diabetic neurons (see Figure 5 in (Akude et al., 2011)).

Another aspect of mitochondrial biology that may be relevant to diabetic neuropathy is the possible involvement of autophagosomes. The presence of increased levels of autophagosomes in DRG neurons of STZ-induced diabetic rats with the co-localization of mitochondria in neuronal soma described by Towns et al. suggests that autophagy may be indicative of, or may contribute to, the mitochondrial dysfunction in diabetic neuropathy (Towns et al., 2008; Towns et al., 2005). Our hypothesis detailing a diabetes-dependent shift towards an anaerobic source of ATP would support the need to remove unnecessary or dysfunctional mitochondria - and this would be reflected by elevated autophagy of this organelle. However, while the work from the Wiley group is interesting further confirmation is needed and in particular ultrastructural identification of autophagosomes is required over a time course of development of diabetic neuropathy. At this juncture numerous electron microscope-based ultrastructural studies of DRG neuronal perikarya from human, STZinduced and BB diabetic rats have been performed over the years but have failed to identify the classic double membrane structure of this organelle (Kamiya et al., 2006; Schmidt et al., 1997b).

In conclusion, we hypothesize that high glucose-induced AMPK/SIRT/PGC-1a downregulation in neurons is a maladaptive process that explains the length dependent loss of distal nerve endings. The constantly plastic axonal endings of fibers in the skin require enormous amounts of ATP to be maintained and to permit collateral sprouting (Bernstein and Bamburg, 2003). This in turn demands a sufficient supply of actively respiring mitochondria. Hyperglycemia-induced loss of the AMPK/SIRT/PGC-1a pathway in diabetic neurons may lead to a dearth of fully functioning mitochondria that ultimately triggers distal axonal death, a hallmark of severe diabetic peripheral neuropathy. 


\section{Summary}

Mitochondrial dysfunction occurs in a range of diabetic complications and given its central role in controlling the bioenergetic status of the cell must be considered a prime trigger of degeneration. It remains unclear how such impaired mitochondrial function triggers cell damage. Enhanced ROS production remains an unproven possibility. Failure to synthesize adequate ATP for high energy requiring axonal functions such as excitation, axonal transport and growth cone motility would seem more attractive options, particularly in neurons. In diabetic neuropathy, studies have begun to outline the array of impairments in mitochondrial physiology, although studies still lag behind those in nephropathy and cardiomyopathy. Diabetes-induced changes in mitochondrial phenotype would seem key factors leading to altered activity of the respiratory chain and Krebs cycle components. Aberrant growth factor-dependent signaling, especially through the insulin pathway could be involved (Ishii, 1995; Zochodne, 2008), however, hyperglycemia and associated raising of intracellular glucose concentration maybe a central trigger of altered mitochondrial proteome expression. In many cell types, high intracellular glucose causes inhibition of oxidative phosphorylation and enhances anaerobic glucose metabolism through glycolysis, known as the Crabtree effect (Ibsen, 1961). The glucose-dependent signal transduction pathway that is proposed to become active in the diabetic state and that initiates altered cell bioenergetics in neurons needs to be dissected and manipulated in vitro and in vivo. There is a plausible role for the polyol pathway in such a paradigm, however, it must be remembered that neurons do not express aldose reductase and so the activity of such a pathway in neurons in diabetes remains unclear (Jiang et al., 2006).

The involvement of deacytylases, such as the sirtuins, along with AMPK and PGC-1a in the mitochondrial dysfunction seen in sensory neuropathy could explain the broad array of phenotypic changes that underlie the altered mitochondrial physiology observed. There is a strong level of inter-dependence between the AMPK, SIRT and PGCla components in diabetic neuropathy. Therefore, a focus on the AMPK/SIRT/PGC-1a pathway in sensory neurons will provide a novel approach to explaining its role on the pathogenesis of the distal axonopathy seen in diabetes and its potential for pharmacologic targeting to help reverse features of the sensory neuropathy. However, given the central nature of this pathway to energy homeostasis in numerous tissues, a major challenge will likely be avoiding untoward side effects that impair their function in non-target tissues.

\section{Acknowledgments}

Dr. Roy Chowdhury was supported by grants to P.F. from CIHR (grant \# MOP-84214) and Juvenile Diabetes Research Foundation (grant \# 1-2008-193). This work was also funded by the St Boniface General Hospital and Research Foundation. This work was also supported by grants from the Juvenile Diabetes Research Foundation (JDRF \# 1-2008-280, 17-2010-760) and The National Institutes of Health (NIH; grants NS054847 and DK073594) to R.T.D.

\section{References}

Abdul-Ghani MA, Jani R, Chavez A, Molina-Carrion M, Tripathy D, Defronzo RA. Mitochondrial reactive oxygen species generation in obese non-diabetic and type 2 diabetic participants. Diabetologia. 2009; 52:574-582. [PubMed: 19183935]

Akude E, Zherebitskaya E, Chowdhury SK, Smith DR, Dobrowsky RT, Fernyhough P. Diminished superoxide generation is associated with respiratory chain dysfunction and changes in the mitochondrial proteome of sensory neurons from diabetic rats. Diabetes. 2011; 60:288-297. [PubMed: 20876714]

Balestrieri ML, Rienzo M, Felice F, Rossiello R, Grimaldi V, Milone L, Casamassimi A, Servillo L, Farzati B, Giovane A, Napoli C. High glucose downregulates endothelial progenitor cell number via SIRT1. Biochim Biophys Acta. 2008; 1784:936-945. [PubMed: 18423418] 
Baloh RH, Schmidt RE, Pestronk A, Milbrandt J. Altered axonal mitochondrial transport in the pathogenesis of Charcot-Marie-Tooth disease from mitofusin 2 mutations. J Neurosci. 2007; 27:422-430. [PubMed: 17215403]

Bao J, Sack MN. Protein deacetylation by sirtuins: delineating a post-translational regulatory program responsive to nutrient and redox stressors. Cell Mol Life Sci. 2010; 67:3073-3087. [PubMed: 20680393]

Bernstein BW, Bamburg JR. Actin-ATP hydrolysis is a major energy drain for neurons. J Neurosci. 2003; 23:1-6. [PubMed: 12514193]

Boushel R, Gnaiger E, Schjerling P, Skovbro M, Kraunsoe R, Dela F. Patients with type 2 diabetes have normal mitochondrial function in skeletal muscle. Diabetologia. 2007; 50:790-796. [PubMed: 17334651]

Bugger H, Boudina S, Hu XX, Tuinei J, Zaha VG, Theobald HA, Yun UJ, McQueen AP, Wayment B, Litwin SE, Abel ED. Type 1 diabetic akita mouse hearts are insulin sensitive but manifest structurally abnormal mitochondria that remain coupled despite increased uncoupling protein 3. Diabetes. 2008; 57:2924-2932. [PubMed: 18678617]

Bugger H, Chen D, Riehle C, Soto J, Theobald HA, Hu XX, Ganesan B, Weimer BC, Abel ED. Tissue-Specific Remodeling of the Mitochondrial Proteome in Type 1 Diabetic Akita Mice. Diabetes. 2009

Calcutt NA, Jolivalt CG, Fernyhough P. Growth factors as therapeutics for diabetic neuropathy. Curr Drug Targets. 2008; 9:47-59. [PubMed: 18220712]

Cameron NE, Eaton SE, Cotter MA, Tesfaye S. Vascular factors and metabolic interactions in the pathogenesis of diabetic neuropathy. Diabetologia. 2001; 44:1973-1988. [PubMed: 11719828]

Canto C, Auwerx J. PGC-1alpha, SIRT1 and AMPK, an energy sensing network that controls energy expenditure. Curr Opin Lipidol. 2009; 20:98-105. [PubMed: 19276888]

Canto C, Auwerx J. AMP-activated protein kinase and its downstream transcriptional pathways. Cell Mol Life Sci. 2010; 67:3407-3423. [PubMed: 20640476]

Chowdhury SK, Zherebitskaya E, Smith DR, Akude E, Chattopadhyay S, Jolivalt CG, Calcutt NA, Fernyhough P. Mitochondrial respiratory chain dysfunction in dorsal root ganglia of streptozotocin-induced diabetic rats and its correction by insulin treatment. Diabetes. 2010; 59:1082-1091. [PubMed: 20103706]

Coppey LJ, Gellett JS, Davidson EP, Yorek MA. Preventing superoxide formation in epineurial arterioles of the sciatic nerve from diabetic rats restores endothelium-dependent vasodilation. Free Radic Res. 2003; 37:33-40. [PubMed: 12653215]

Courchesne SL, Karch C, Pazyra-Murphy MF, Segal RA. Sensory neuropathy attributable to loss of bcl-w. Journal of Neuroscience. 2011; 31:1624-1634. [PubMed: 21289171]

da Silva Xavier G, Leclerc I, Varadi A, Tsuboi T, Moule SK, Rutter GA. Role for AMP-activated protein kinase in glucose-stimulated insulin secretion and preproinsulin gene expression. Biochem J. 2003; 371:761-774. [PubMed: 12589707]

Dabkowski ER, Williamson CL, Bukowski VC, Chapman RS, Leonard SS, Peer CJ, Callery PS, Hollander JM. Diabetic cardiomyopathy-associated dysfunction in spatially distinct mitochondrial subpopulations. Am J Physiol Heart Circ Physiol. 2009; 296:H359-369. [PubMed: 19060128]

Dasgupta B, Milbrandt J. Resveratrol stimulates AMP kinase activity in neurons. Proc Natl Acad Sci U S A. 2007; 104:7217-7222. [PubMed: 17438283]

de Cavanagh EM, Ferder L, Toblli JE, Piotrkowski B, Stella I, Fraga CG, Inserra F. Renal mitochondrial impairment is attenuated by AT1 blockade in experimental Type I diabetes. Am J Physiol Heart Circ Physiol. 2008; 294:H456-465. [PubMed: 18024545]

De Feyter HM, Lenaers E, Houten SM, Schrauwen P, Hesselink MK, Wanders RJ, Nicolay K, Prompers JJ. Increased intramyocellular lipid content but normal skeletal muscle mitochondrial oxidative capacity throughout the pathogenesis of type 2 diabetes. Faseb J. 2008; 22:3947-3955. [PubMed: 18653763]

Duran-Jimenez B, Dobler D, Moffatt S, Rabbani N, Streuli CH, Thornalley PJ, Tomlinson DR, Gardiner NJ. Advanced glycation end products in extracellular matrix proteins contribute to the failure of sensory nerve regeneration in diabetes. Diabetes. 2009; 58:2893-2903. [PubMed: 19720799] 
Eichberg J. Protein kinase C changes in diabetes: is the concept relevant to neuropathy? Int Rev Neurobiol. 2002; 50:61-82. [PubMed: 12198821]

Estrella JS, Nelson RN, Sturges BK, Vernau KM, Williams DC, LeCouteur RA, Shelton GD, Mizisin AP. Endoneurial microvascular pathology in feline diabetic neuropathy. Microvasc Res. 2008; 75:403-410. [PubMed: 18207200]

Feige JN, Auwerx J. Transcriptional coregulators in the control of energy homeostasis. Trends Cell Biol. 2007; 17:292-301. [PubMed: 17475497]

Fernyhough P, Schmidt RE. Neurofilaments in diabetic neuropathy. Int Rev Neurobiol. 2002; 50:115144. [PubMed: 12198808]

Garcia-Roves PM, Osler ME, Holmstrom MH, Zierath JR. Gain-of-function R225Q mutation in AMPactivated protein kinase gamma3 subunit increases mitochondrial biogenesis in glycolytic skeletal muscle. J Biol Chem. 2008; 283:35724-35734. [PubMed: 18838377]

Hall KE, Sima AA, Wiley JW. Voltage-dependent calcium currents are enhanced in dorsal root ganglion neurones from the Bio Bred/Worchester diabetic rat. J Physiol. 1995; 486 ( Pt 2):313322. [PubMed: 7473199]

Handschin C, Chin S, Li P, Liu F, Maratos-Flier E, Lebrasseur NK, Yan Z, Spiegelman BM. Skeletal muscle fiber-type switching, exercise intolerance, and myopathy in PGC-1alpha muscle-specific knock-out animals. J Biol Chem. 2007; 282:30014-30021. [PubMed: 17702743]

Hardie DG. AMP-activated/SNF1 protein kinases: conserved guardians of cellular energy. Nat Rev Mol Cell Biol. 2007; 8:774-785. [PubMed: 17712357]

Hardie DG. AMPK: a key regulator of energy balance in the single cell and the whole organism. Int J Obes (Lond). 2008; 32(Suppl 4):S7-12. [PubMed: 18719601]

Herlein JA, Fink BD, O’Malley Y, Sivitz WI. Superoxide and respiratory coupling in mitochondria of insulin-deficient diabetic rats. Endocrinology. 2009; 150:46-55. [PubMed: 18772240]

Ho EC, Lam KS, Chen YS, Yip JC, Arvindakshan M, Yamagishi S, Yagihashi S, Oates PJ, Ellery CA, Chung SS, Chung SK. Aldose reductase-deficient mice are protected from delayed motor nerve conduction velocity, increased c-Jun NH2-terminal kinase activation, depletion of reduced glutathione, increased superoxide accumulation, and DNA damage. Diabetes. 2006; 55:19461953. [PubMed: 16804062]

Huang TJ, Price SA, Chilton L, Calcutt NA, Tomlinson DR, Verkhratsky A, Fernyhough P. Insulin prevents depolarization of the mitochondrial inner membrane in sensory neurons of type 1 diabetic rats in the presence of sustained hyperglycemia. Diabetes. 2003; 52:2129-2136. [PubMed: 12882932]

Huang TJ, Sayers NM, Fernyhough P, Verkhratsky A. Diabetes-induced alterations in calcium homeostasis in sensory neurones of streptozotocin-diabetic rats are restricted to lumbar ganglia and are prevented by neurotrophin-3. Diabetologia. 2002; 45:560-570. [PubMed: 12032634]

Huang TJ, Sayers NM, Verkhratsky A, Fernyhough P. Neurotrophin-3 prevents mitochondrial dysfunction in sensory neurons of streptozotocin-diabetic rats. Exp Neurol. 2005; 194:279-283. [PubMed: 15899264]

Ibsen HK. The Crabtree effect: a review. Cancer Research. 1961; 21:829-841. [PubMed: 13717358]

Ido Y, Nyengaard JR, Chang K, Tilton RG, Kilo C, Mylari BL, Oates PJ, Williamson JR. Early neural and vascular dysfunctions in diabetic rats are largely sequelae of increased sorbitol oxidation. Antioxid Redox Signal. 2010; 12:39-51. [PubMed: 19624259]

Ishii DN. Implication of insulin-like growth factors in the pathogenesis of diabetic neuropathy. Brain Res Brain Res Rev. 1995; 20:47-67. [PubMed: 7711767]

Iwabu M, Yamauchi T, Okada-Iwabu M, Sato K, Nakagawa T, Funata M, Yamaguchi M, Namiki S, Nakayama R, Tabata M, Ogata H, Kubota N, Takamoto I, Hayashi YK, Yamauchi N, Waki H, Fukayama M, Nishino I, Tokuyama K, Ueki K, Oike Y, Ishii S, Hirose K, Shimizu T, Touhara K, Kadowaki T. Adiponectin and AdipoR1 regulate PGC-1alpha and mitochondria by $\mathrm{Ca}(2+)$ and AMPK/SIRT1. Nature. 2010; 464:1313-1319. [PubMed: 20357764]

Jager S, Handschin C, St-Pierre J, Spiegelman BM. AMP-activated protein kinase (AMPK) action in skeletal muscle via direct phosphorylation of PGC-1alpha. Proc Natl Acad Sci U S A. 2007; 104:12017-12022. [PubMed: 17609368] 
Jiang Y, Calcutt NA, Ramos KM, Mizisin AP. Novel sites of aldose reductase immunolocalization in normal and streptozotocin-diabetic rats. J Peripher Nerv Syst. 2006; 11:274-285. [PubMed: 17117935]

Kamboj SS, Sandhir R. Protective effect of N-acetylcysteine supplementation on mitochondrial oxidative stress and mitochondrial enzymes in cerebral cortex of streptozotocin-treated diabetic rats. Mitochondrion. 2010; 11:214-222. [PubMed: 21059408]

Kamiya H, Zhang W, Sima AA. Degeneration of the Golgi and neuronal loss in dorsal root ganglia in diabetic BioBreeding/Worcester rats. Diabetologia. 2006; 49:2763-2774. [PubMed: 17047923]

Kamiya H, Zhangm W, Sima AA. Apoptotic stress is counterbalanced by survival elements preventing programmed cell death of dorsal root ganglions in subacute type 1 diabetic BB/Wor rats. Diabetes. 2005; 54:3288-3295. [PubMed: 16249457]

Kelley DE, He J, Menshikova EV, Ritov VB. Dysfunction of mitochondria in human skeletal muscle in type 2 diabetes. Diabetes. 2002; 51:2944-2950. [PubMed: 12351431]

Kennedy JM, Zochodne DW. Experimental diabetic neuropathy with spontaneous recovery: is there irreparable damage? Diabetes. 2005; 54:830-837. [PubMed: 15734862]

Kennedy WR, Wendelschafer-Crabb G, Johnson T. Quantitation of epidermal nerves in diabetic neuropathy. Neurology. 1996; 47:1042-1048. [PubMed: 8857742]

Kim D, Nguyen MD, Dobbin MM, Fischer A, Sananbenesi F, Rodgers JT, Delalle I, Baur JA, Sui G, Armour SM, Puigserver P, Sinclair DA, Tsai LH. SIRT1 deacetylase protects against neurodegeneration in models for Alzheimer's disease and amyotrophic lateral sclerosis. EMBO J. 2007; 26:3169-3179. [PubMed: 17581637]

Kruglikov I, Gryshchenko O, Shutov L, Kostyuk E, Kostyuk P, Voitenko N. Diabetes-induced abnormalities in ER calcium mobilization in primary and secondary nociceptive neurons. Pflugers Arch. 2004; 448:395-401. [PubMed: 15048576]

Kumar A, Kaundal RK, Iyer S, Sharma SS. Effects of resveratrol on nerve functions, oxidative stress and DNA fragmentation in experimental diabetic neuropathy. Life Sci. 2007; 80:1236-1244. [PubMed: 17289084]

Lan F, Cacicedo JM, Ruderman N, Ido Y. SIRT1 modulation of the acetylation status, cytosolic localization, and activity of LKB1. Possible role in AMP-activated protein kinase activation. J Biol Chem. 2008; 283:27628-27635. [PubMed: 18687677]

Lashin OM, Szweda PA, Szweda LI, Romani AM. Decreased complex II respiration and HNEmodified SDH subunit in diabetic heart. Free Radic Biol Med. 2006; 40:886-896. [PubMed: 16520240]

Li F, Szabo C, Pacher P, Southan GJ, Abatan OI, Charniauskaya T, Stevens MJ, Obrosova IG. Evaluation of orally active poly(ADP-ribose) polymerase inhibitor in streptozotocin-diabetic rat model of early peripheral neuropathy. Diabetologia. 2004; 47:710-717. [PubMed: 15298348]

Lin J, Wu H, Tarr PT, Zhang CY, Wu Z, Boss O, Michael LF, Puigserver P, Isotani E, Olson EN, Lowell BB, Bassel-Duby R, Spiegelman BM. Transcriptional co-activator PGC-1 alpha drives the formation of slow-twitch muscle fibres. Nature. 2002; 418:797-801. [PubMed: 12181572]

Malik RA, Tesfaye S, Newrick PG, Walker D, Rajbhandari SM, Siddique I, Sharma AK, Boulton AJ, King RH, Thomas PK, Ward JD. Sural nerve pathology in diabetic patients with minimal but progressive neuropathy. Diabetologia. 2005; 48:578-585. [PubMed: 15729579]

Michael LF, Wu Z, Cheatham RB, Puigserver P, Adelmant G, Lehman JJ, Kelly DP, Spiegelman BM. Restoration of insulin-sensitive glucose transporter (GLUT4) gene expression in muscle cells by the transcriptional coactivator PGC-1. Proc Natl Acad Sci U S A. 2001; 98:3820-3825. [PubMed: 11274399]

Mizisin AP, Nelson RW, Sturges BK, Vernau KM, Lecouteur RA, Williams DC, Burgers ML, Shelton GD. Comparable myelinated nerve pathology in feline and human diabetes mellitus. Acta Neuropathol. 2007; 113:431-442. [PubMed: 17237938]

Mizisin AP, Shelton GD, Burgers ML, Powell HC, Cuddon PA. Neurological complications associated with spontaneously occurring feline diabetes mellitus. J Neuropathol Exp Neurol. 2002; 61:872884. [PubMed: 12387453] 
Mogensen M, Sahlin K, Fernstrom M, Glintborg D, Vind BF, Beck-Nielsen H, Hojlund K. Mitochondrial respiration is decreased in skeletal muscle of patients with type 2 diabetes. Diabetes. 2007; 56:1592-1599. [PubMed: 17351150]

Mootha VK, Lindgren CM, Eriksson KF, Subramanian A, Sihag S, Lehar J, Puigserver P, Carlsson E, Ridderstrale M, Laurila E, Houstis N, Daly MJ, Patterson N, Mesirov JP, Golub TR, Tamayo P, Spiegelman B, Lander ES, Hirschhorn JN, Altshuler D, Groop LC. PGC-1alpha-responsive genes involved in oxidative phosphorylation are coordinately downregulated in human diabetes. Nat Genet. 2003; 34:267-273. [PubMed: 12808457]

Mountjoy PD, Bailey SJ, Rutter GA. Inhibition by glucose or leptin of hypothalamic neurons expressing neuropeptide $\mathrm{Y}$ requires changes in AMP-activated protein kinase activity. Diabetologia. 2007; 50:168-177. [PubMed: 17093945]

Mountjoy PD, Rutter GA. Glucose sensing by hypothalamic neurones and pancreatic islet cells: AMPle evidence for common mechanisms? Exp Physiol. 2007; 92:311-319. [PubMed: 17158178]

Munusamy S, Saba H, Mitchell T, Megyesi JK, Brock RW, Macmillan-Crow LA. Alteration of renal respiratory Complex-III during experimental type-1 diabetes. BMC Endocr Disord. 2009; 9:2. [PubMed: 19166612]

Nemoto S, Fergusson MM, Finkel T. SIRT1 functionally interacts with the metabolic regulator and transcriptional coactivator PGC-1 \{alpha\}. J Biol Chem. 2005; 280:16456-16460. [PubMed: 15716268]

Nishikawa T, Edelstein D, Brownlee M. The missing link: a single unifying mechanism for diabetic complications. Kidney Int Suppl. 2000a; 77:S26-30. [PubMed: 10997687]

Nishikawa T, Edelstein D, Du XL, Yamagishi S, Matsumura T, Kaneda Y, Yorek MA, Beebe D, Oates PJ, Hammes HP, Giardino I, Brownlee M. Normalizing mitochondrial superoxide production blocks three pathways of hyperglycaemic damage. Nature. 2000b; 404:787-790. [PubMed: 10783895]

Nja A, Purves D. The effects of nerve growth factor and its antiserum on synapses in the superior cervical ganglion of the guinea-pig. J Physiol. 1978; 277:53-75. [PubMed: 206691]

Oates PJ. Polyol pathway and diabetic peripheral neuropathy. Int Rev Neurobiol. 2002; 50:325-392. [PubMed: 12198816]

Oates PJ. Aldose reductase, still a compelling target for diabetic neuropathy. Curr Drug Targets. 2008; 9:14-36. [PubMed: 18220710]

Obrosova IG. How does glucose generate oxidative stress in peripheral nerve? Int Rev Neurobiol. 2002; 50:3-35. [PubMed: 12198815]

Obrosova IG, Drel VR, Kumagai AK, Szabo C, Pacher P, Stevens MJ. Early diabetes-induced biochemical changes in the retina: comparison of rat and mouse models. Diabetologia. 2006; 49:2525-2533. [PubMed: 16896942]

Obrosova IG, Drel VR, Pacher P, Ilnytska O, Wang ZQ, Stevens MJ, Yorek MA. OxidativeNitrosative Stress and Poly(ADP-Ribose) Polymerase (PARP) Activation in Experimental Diabetic Neuropathy: The Relation Is Revisited. Diabetes. 2005a; 54:3435-3441. [PubMed: 16306359]

Obrosova IG, Pacher P, Szabo C, Zsengeller Z, Hirooka H, Stevens MJ, Yorek MA. Aldose reductase inhibition counteracts oxidative-nitrosative stress and poly(ADP-ribose) polymerase activation in tissue sites for diabetes complications. Diabetes. 2005b; 54:234-242. [PubMed: 15616034]

Obrosova IG, Van Huysen C, Fathallah L, Cao XC, Greene DA, Stevens MJ. An aldose reductase inhibitor reverses early diabetes-induced changes in peripheral nerve function, metabolism, and antioxidative defense. FASEB J. 2002; 16:123-125. [PubMed: 11709499]

Oltman CL, Davidson EP, Coppey LJ, Kleinschmidt TL, Yorek MA. Treatment of Zucker diabetic fatty rats with AVE7688 improves vascular and neural dysfunction. Diabetes Obes Metab. 2009; 11:223-233. [PubMed: 18564175]

Patti ME, Butte AJ, Crunkhorn S, Cusi K, Berria R, Kashyap S, Miyazaki Y, Kohane I, Costello M, Saccone R, Landaker EJ, Goldfine AB, Mun E, DeFronzo R, Finlayson J, Kahn CR, Mandarino LJ. Coordinated reduction of genes of oxidative metabolism in humans with insulin resistance and diabetes: Potential role of PGC1 and NRF1. Proc Natl Acad Sci U S A. 2003; 100:8466-8471. [PubMed: 12832613] 
Pazyra-Murphy MF, Hans A, Courchesne SL, Karch C, Cosker KE, Heerssen HM, Watson FL, Kim T, Greenberg ME, Segal RA. A retrograde neuronal survival response: target-derived neurotrophins regulate MEF2D and bcl-w. J Neurosci. 2009; 29:6700-6709. [PubMed: 19458239]

Phielix E, Schrauwen-Hinderling VB, Mensink M, Lenaers E, Meex R, Hoeks J, Kooi ME, MoonenKornips E, Sels JP, Hesselink MK, Schrauwen P. Lower intrinsic ADP-stimulated mitochondrial respiration underlies in vivo mitochondrial dysfunction in muscle of male type 2 diabetic patients. Diabetes. 2008; 57:2943-2949. [PubMed: 18678616]

Polydefkis M, Hauer P, Sheth S, Sirdofsky M, Griffin JW, McArthur JC. The time course of epidermal nerve fibre regeneration: studies in normal controls and in people with diabetes, with and without neuropathy. Brain. 2004; 127:1606-1615. [PubMed: 15128618]

Puigserver P, Rhee J, Donovan J, Walkey CJ, Yoon JC, Oriente F, Kitamura Y, Altomonte J, Dong H, Accili D, Spiegelman BM. Insulin-regulated hepatic gluconeogenesis through FOXO1PGC-1alpha interaction. Nature. 2003; 423:550-555. [PubMed: 12754525]

Puigserver P, Wu Z, Park CW, Graves R, Wright M, Spiegelman BM. A cold-inducible coactivator of nuclear receptors linked to adaptive thermogenesis. Cell. 1998; 92:829-839. [PubMed: 9529258]

Rabol R, Hojberg PM, Almdal T, Boushel R, Haugaard SB, Madsbad S, Dela F. Effect of hyperglycemia on mitochondrial respiration in type 2 diabetes. J Clin Endocrinol Metab. 2009a; 94:1372-1378. [PubMed: 19141588]

Rabol R, Hojberg PM, Almdal T, Boushel R, Haugaard SB, Madsbad S, Dela F. Improved glycaemic control decreases inner mitochondrial membrane leak in type 2 diabetes. Diabetes Obes Metab. 2009b; 11:355-360. [PubMed: 19267714]

Rabol R, Svendsen PF, Skovbro M, Boushel R, Haugaard SB, Schjerling P, Schrauwen P, Hesselink MK, Nilas L, Madsbad S, Dela F. Reduced skeletal muscle mitochondrial respiration and improved glucose metabolism in nondiabetic obese women during a very low calorie dietary intervention leading to rapid weight loss. Metabolism. 2009c; 58:1145-1152. [PubMed: 19454354]

Reznick RM, Shulman GI. The role of AMP-activated protein kinase in mitochondrial biogenesis. J Physiol. 2006; 574:33-39. [PubMed: 16709637]

Richardson DK, Kashyap S, Bajaj M, Cusi K, Mandarino SJ, Finlayson J, DeFronzo RA, Jenkinson $\mathrm{CP}$, Mandarino LJ. Lipid infusion decreases the expression of nuclear encoded mitochondrial genes and increases the expression of extracellular matrix genes in human skeletal muscle. J Biol Chem. 2005; 280:10290-10297. [PubMed: 15598661]

Rodgers JT, Lerin C, Gerhart-Hines Z, Puigserver P. Metabolic adaptations through the PGC-1 alpha and SIRT1 pathways. FEBS Lett. 2008; 582:46-53. [PubMed: 18036349]

Rodgers JT, Lerin C, Haas W, Gygi SP, Spiegelman BM, Puigserver P. Nutrient control of glucose homeostasis through a complex of PGC-1alpha and SIRT1. Nature. 2005; 434:113-118. [PubMed: 15744310]

Russell JW, Golovoy D, Vincent AM, Mahendru P, Olzmann JA, Mentzer A, Feldman EL. High glucose-induced oxidative stress and mitochondrial dysfunction in neurons. Faseb J. 2002; 16:1738-1748. [PubMed: 12409316]

Schmidt RE, Beaudet LN, Plurad SB, Dorsey DA. Axonal cytoskeletal pathology in aged and diabetic human sympathetic autonomic ganglia. Brain Res. 1997a; 769:375-383. [PubMed: 9374210]

Schmidt RE, Dorsey D, Parvin CA, Beaudet LN, Plurad SB, Roth KA. Dystrophic axonal swellings develop as a function of age and diabetes in human dorsal root ganglia. J Neuropathol Exp Neurol. 1997b; 56:1028-1043. [PubMed: 9291944]

Sharma SS, Kumar A, Arora M, Kaundal RK. Neuroprotective potential of combination of resveratrol and 4-amino 1,8 naphthalimide in experimental diabetic neuropathy: focus on functional, sensorimotor and biochemical changes. Free Radic Res. 2009; 43:400-408. [PubMed: 19291593]

Shen W, Hao J, Tian C, Ren J, Yang L, Li X, Luo C, Cotma CW, Liu J. A combination of nutriments improves mitochondrial biogenesis and function in skeletal muscle of type 2 diabetic GotoKakizaki rats. PLoS One. 2008; 3:e2328. [PubMed: 18523557]

Shen X, Zheng S, Thongboonkerd V, Xu M, Pierce WM Jr, Klein JB, Epstein PN. Cardiac mitochondrial damage and biogenesis in a chronic model of type 1 diabetes. Am J Physiol Endocrinol Metab. 2004; 287:E896-905. [PubMed: 15280150] 
Sidenius P, Jakobsen J. Reduced perikaryal volume of lower motor and primary sensory neurons in early experimental diabetes. Diabetes. 1980; 29:182-186. [PubMed: 7380109]

Sima AA. Diabetic neuropathy in type 1 and type 2 diabetes and the effects of C-peptide. J Neurol Sci. 2004; 220:133-136. [PubMed: 15140622]

Sivitz WI, Yorek MA. Mitochondrial dysfunction in diabetes: from molecular mechanisms to functional significance and therapeutic opportunities. Antioxid Redox Signal. 2010; 12:537-577. [PubMed: 19650713]

Srinivasan S, Stevens M, Wiley JW. Diabetic peripheral neuropathy: evidence for apoptosis and associated mitochondrial dysfunction. Diabetes. 2000; 49:1932-1938. [PubMed: 11078462]

St-Pierre J, Drori S, Uldry M, Silvaggi JM, Rhee J, Jager S, Handschin C, Zheng K, Lin J, Yang W, Simon DK, Bachoo R, Spiegelman BM. Suppression of reactive oxygen species and neurodegeneration by the PGC-1 transcriptional coactivators. Cell. 2006; 127:397-408. [PubMed: 17055439]

Thornalley PJ. Glycation in diabetic neuropathy: characteristics, consequences, causes, and therapeutic options. Int Rev Neurobiol. 2002; 50:37-57. [PubMed: 12198817]

Towns R, Guo C, Shangguan Y, Hong S, Wiley JW. Type 2 diabetes with neuropathy: autoantibody stimulation of autophagy via Fas. Neuroreport. 2008; 19:265-269. [PubMed: 18303564]

Towns R, Kabeya Y, Yoshimori T, Guo C, Shangguan Y, Hong S, Kaplan M, Klionsky DJ, Wiley JW. Sera from patients with type 2 diabetes and neuropathy induce autophagy and colocalization with mitochondria in SY5Y cells. Autophagy. 2005; 1:163-170. [PubMed: 16874076]

Vega RB, Huss JM, Kelly DP. The coactivator PGC-1 cooperates with peroxisome proliferatoractivated receptor alpha in transcriptional control of nuclear genes encoding mitochondrial fatty acid oxidation enzymes. Mol Cell Biol. 2000; 20:1868-1876. [PubMed: 10669761]

Vincent AM, Russell JW, Low P, Feldman EL. Oxidative stress in the pathogenesis of diabetic neuropathy. Endocr Rev. 2004; 25:612-628. [PubMed: 15294884]

Yagihashi S. Pathogenetic mechanisms of diabetic neuropathy: lessons from animal models. J Peripher Nerv Syst. 1997; 2:113-132. [PubMed: 10959225]

Yang JY, Yeh HY, Lin K, Wang PH. Insulin stimulates Akt translocation to mitochondria: implications on dysregulation of mitochondrial oxidative phosphorylation in diabetic myocardium. J Mol Cell Cardiol. 2009; 46:919-926. [PubMed: 19249309]

Yorek MA, Coppey LJ, Gellett JS, Davidson EP, Lund DD. Effect of fidarestat and alpha-lipoic acid on diabetes-induced epineurial arteriole vascular dysfunction. Exp Diabesity Res. 2004; 5:123135. [PubMed: 15203883]

Yu X, Tesiram YA, Towner RA, Abbott A, Patterson E, Huang S, Garrett MW, Chandrasekaran S, Matsuzaki S, Szweda LI, Gordon BE, Kem DC. Early myocardial dysfunction in streptozotocininduced diabetic mice: a study using in vivo magnetic resonance imaging (MRI). Cardiovasc Diabetol. 2007; 6:6. [PubMed: 17309798]

Zherebitskaya E, Akude E, Smith DR, Fernyhough P. Development of selective axonopathy in adult sensory neurons isolated from diabetic rats: role of glucose-induced oxidative stress. Diabetes. 2009; 58:1356-1364. [PubMed: 19252136]

Zochodne DW. Diabetic polyneuropathy: an update. Curr Opin Neurol. 2008; 21:527-533. [PubMed: 18769245]

Zong H, Ren JM, Young LH, Pypaert M, Mu J, Birnbaum MJ, Shulman GI. AMP kinase is required for mitochondrial biogenesis in skeletal muscle in response to chronic energy deprivation. Proc Natl Acad Sci U S A. 2002; 99:15983-15987. [PubMed: 12444247] 


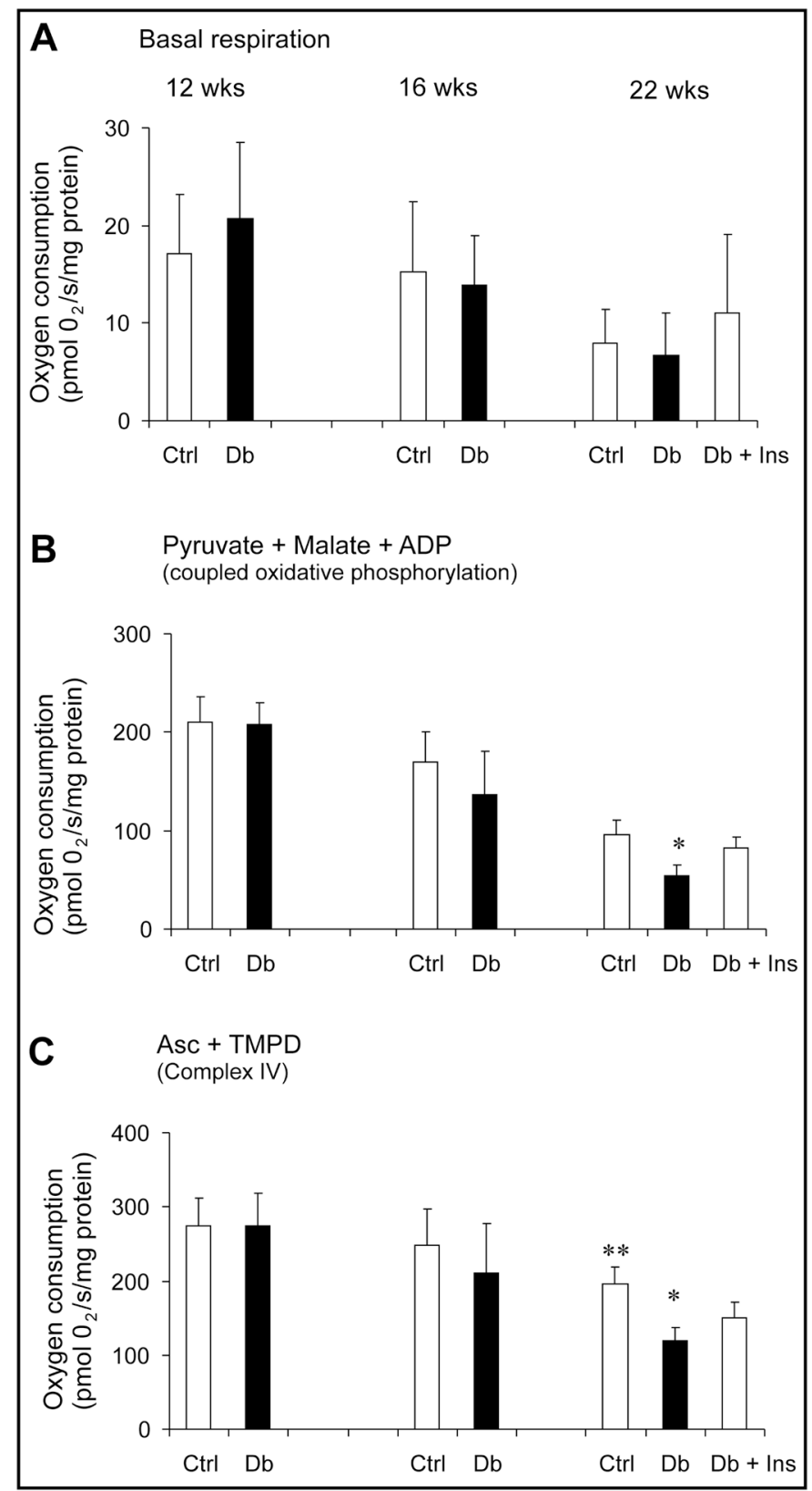

Figure 1. Effect of 12-22 wks of STZ diabetes on the electron transport chain activity of mitochondria in freshly prepared lumbar DRG tissue homogenate

A Clarke type electrode (OROBOROS oxygraph $2 \mathrm{~K}$ ) was used to measure oxygen consumption - a direct measure of rate of electron transport in mitochondria. Measurements of oxygen consumption were performed with energetic substrates, pyruvate and malate. A. Basal respiration, B. Pyruvate + Malate + ADP (coupled oxidative phosphorylation), and C. the respiration rate with Asc + TMPD (Complex IV) were assessed age-matched control (Ctrl), STZ diabetic rats (Db), and STZ diabetic rats with insulin implant (Db + Ins) at 12 (n $=5), 16(\mathrm{n}=7-11)$, and $22(\mathrm{n}=5-6)$ wks of diabetes. Values are means $\pm \mathrm{SD}, \mathrm{n}=\mathrm{as}$ indicated. $* \mathrm{P}<0.05 \mathrm{vs} \mathrm{Db}+\mathrm{Ins} ; * * \mathrm{P}<0.001 \mathrm{vs} \mathrm{Db}$ (one-way ANOVA with Tukey's posthoc comparison). Copyright 2010 American Diabetes Association. From Diabetes, vol. 59, 2010; 1085. Reprinted with permission from the American Diabetes Association. 

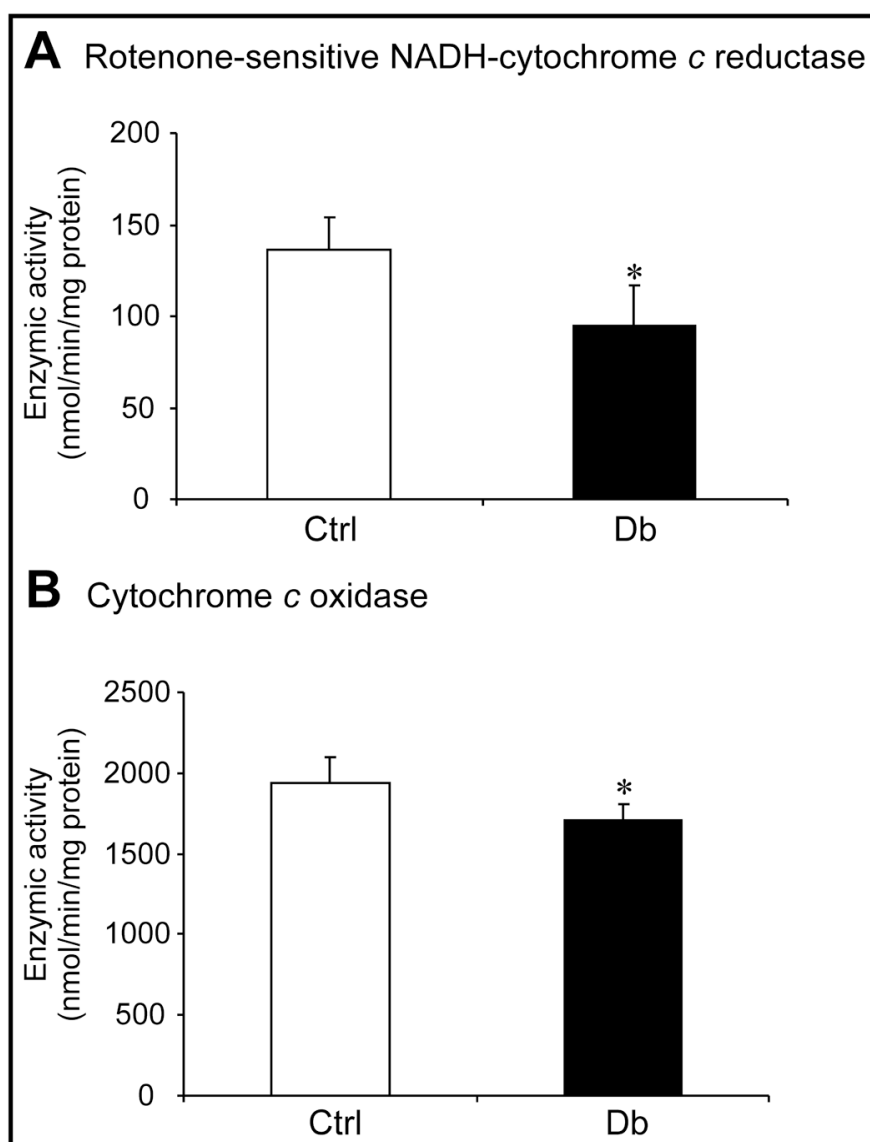

C Citrate synthase

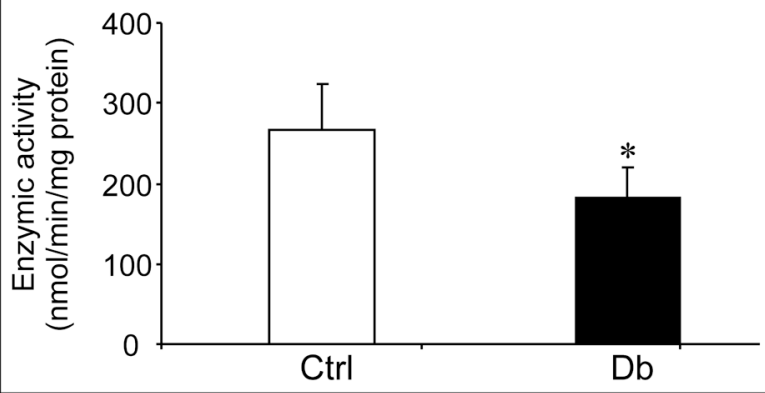

Figure 2. Enzymatic activities of mitochondrial respiratory chain and citrate synthase activity are decreased in isolated mitochondria from lumbar DRG of STZ-diabetic rats

Enzymatic activity of Complex I was assessed as (A) rotenone-sensitive portion of NADHcytochrome $c$ reductase (NCCR) $(\mathrm{n}=5),(\mathrm{B})$ cytochrome $c$ oxidase $(\mathrm{n}=6-7)$ and $(\mathrm{C})$ citrate synthase $(n=5)$ were measured as described in Research Design and Methods. Values are means $\pm \mathrm{SD}, \mathrm{n}=$ as indicated. $* \mathrm{P}<0.05 \mathrm{vs}$ Ctrl (unpaired Student's t-test). Copyright 2010 American Diabetes Association. From Diabetes, vol. 59, 2010; 1087. Reprinted with permission from the American Diabetes Association. 


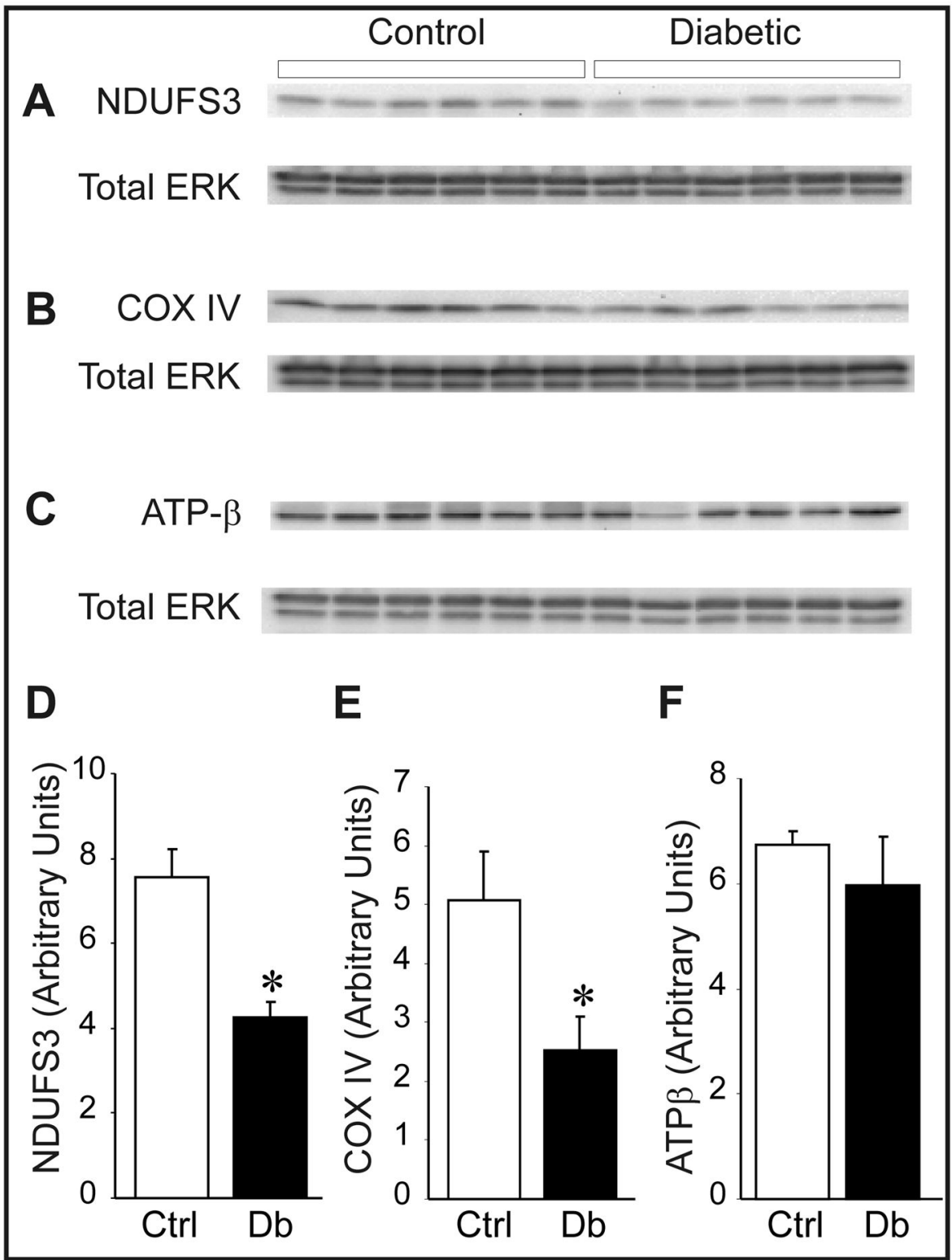

Figure 3. Protein levels of mitochondrial respiratory chain components are reduced in DRG from STZ-diabetic mice

Western blotting revealed diminished expression of some components of the mitochondrial electron transport chain. NDUFS3 (component of Complex I) and COX IV (component of Complex IV) were significantly decreased, whereas levels of ATP-synthase- $\beta$ subunit and ERK remained unaltered. Shown are representative blots $(\mathrm{A}-\mathrm{C})$ and charts in which NDUFS3 (D), COX IV (E), and ATP-synthase $\beta$ subunit signal (F) have been presented relative to total ERK level. Values are means $\pm \mathrm{SEM}, \mathrm{n}=6$. $* \mathrm{P}<0.05$ vs Ctrl (unpaired Student's $t$ test). 


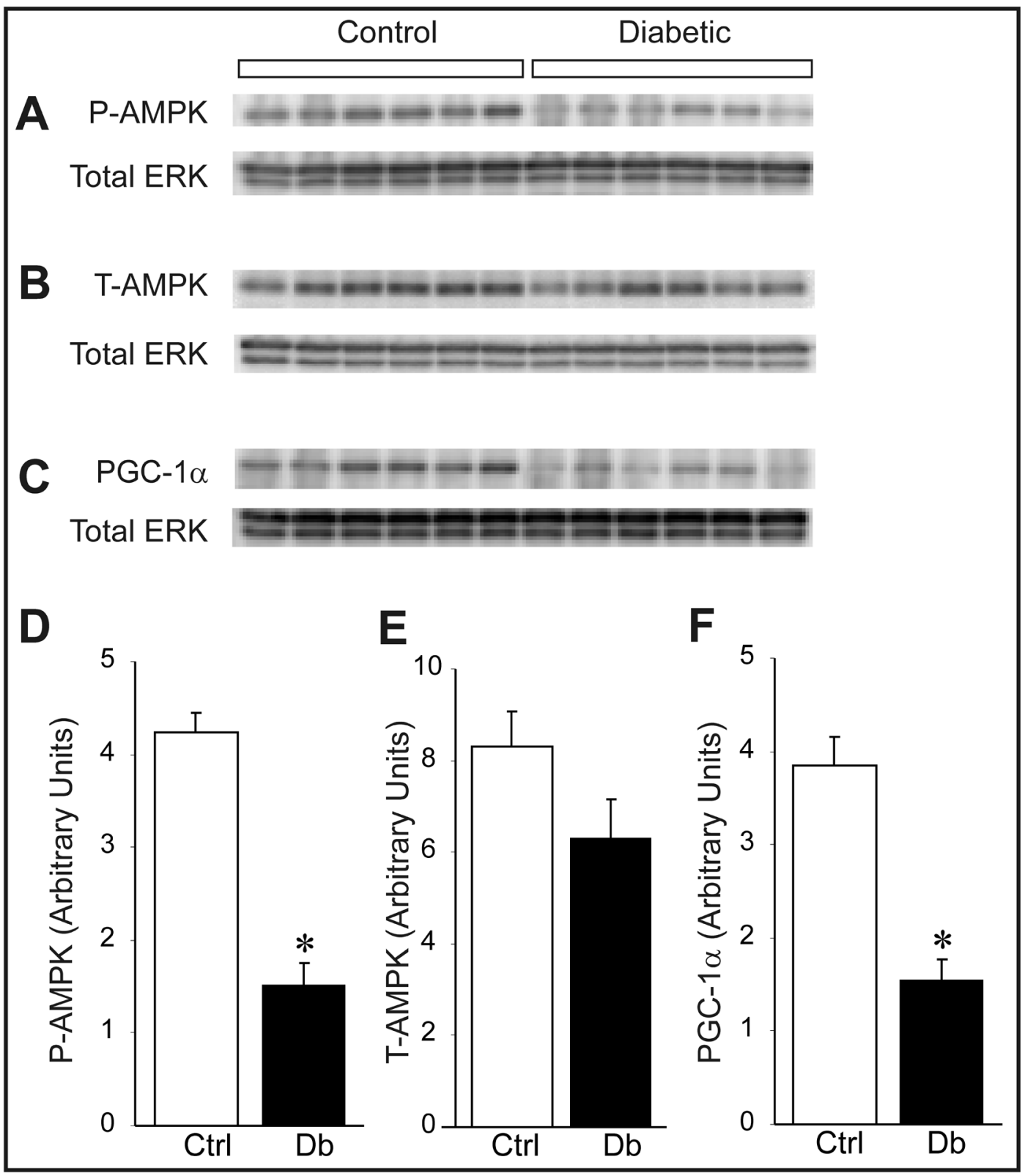

Figure 4. Expressions of P-AMPK and PGC-1a are down-regulated in STZ-diabetic mice A down-regulation of mitochondrial proteins was associated with lowered activation status of the up-stream regulators of mitochondrial biogenesis, AMPK and PGC-1a. The Western blotting expressed reduced activation of phosphorylated AMPK (P-AMPK) coupled with diminished level of PGC-1a whereas total AMPK (T-AMPK) and ERK remain unchanged. Shown are representative blots $(\mathrm{A}-\mathrm{C})$ and charts in which P-AMPK (D), T-AMPK (E), and PGC-1a signal (F) have been presented relative to total ERK level. Values are means \pm $\mathrm{SEM}, \mathrm{n}=6$. $* \mathrm{P}<0.05$ vs Ctrl (unpaired Student's $t$ test). 


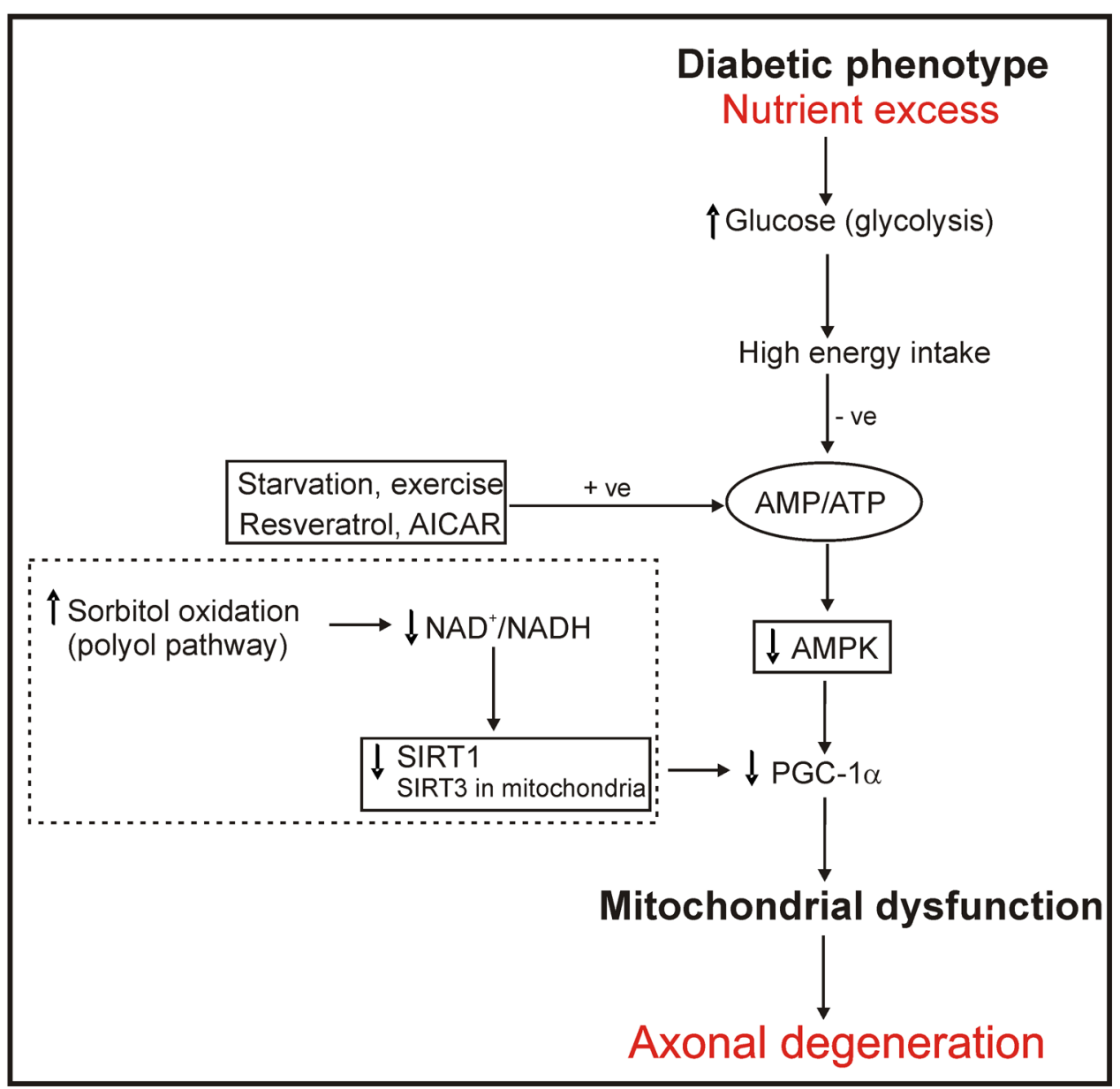

Figure 5. Mitochondrial dysfunction in sensory neurons due to diabetes through the AMPK/ SIRT/PGC-1 a pathway

Nutrient excess or hyperglycemia combines to alter mitochondrial function. High intracellular [glucose] in neurons may cause a general downregulation of mitochondrial oxidative capacity, possibly through the involvement of AMPK/PGC-1a pathway. Under nutrient depletion (starvation, exercise) or the influence of resveratrol or AICAR, the pathway is activated. In addition, elevated glucose flux through the polyol pathway leads to high rates of sorbitol oxidation and a decrease in the cytoplasmic and mitochondrial $\mathrm{NAD}^{+} /$ NADH ratio. This will effectively lower $\mathrm{NAD}^{+}$levels and reduce SIRT1/3 activity. There is also a positive feedback loop linking AMPK with SIRT1 wherein SIRT1 elevates AMPK activity through deacetylation of LKB1 and AMPK enhances SIRT1 through elevation of $\mathrm{NAD}^{+}$. 


\section{TABLE 1}

Summary of mitochondrial alterations in tissues affected by diabetes.

\begin{tabular}{|c|c|c|}
\hline Diabetic model, tissue/culture & Aberrant mitochondrial physiology & References \\
\hline \multicolumn{3}{|l|}{ Type 1 diabetes } \\
\hline STZ-rat, cerebral cortex & $\begin{array}{l}\downarrow \text { Enzymatic activity (Complex I, II and IV) } \\
\downarrow \text { Protein level of Mn-SOD } \\
\uparrow \text { Cytochrome } c \text { release, caspase-3 Presence of mitochondrial } \\
\text { swelling } \\
\downarrow \text { Mitochondrial thiol content }\end{array}$ & $\begin{array}{l}\text { (Kamboj and Sandhir, } \\
\text { 2010) }\end{array}$ \\
\hline STZ-mice, myocardium & $\begin{array}{l}\downarrow \text { Respiration (Complex I, II, and IV) } \\
\downarrow \text { Enzymatic activity of Complexes I, III and V } \\
\downarrow \text { mitochondrial content (mt-DNA) }\end{array}$ & $\begin{array}{l}\text { (Dabkowski et al., 2009; } \\
\text { Yang et al., 2009; Yu et al., } \\
\text { 2007) }\end{array}$ \\
\hline STZ-rat, heart & $\begin{array}{l}\downarrow \text { Respiration (glutamate }+ \text { malate, succinate, FCCP) } \\
\downarrow \text { Enzymatic activity of Complex I and II; } \uparrow \text { UCP3, } \downarrow \text { ANT1 }\end{array}$ & $\begin{array}{l}\text { (Herlein et al., 2009; Lashin } \\
\text { et al., 2006) }\end{array}$ \\
\hline Chronic OVE26 diabetic mice, heart & $\downarrow$ Respiratory rate at state 3 and 4 , respiratory ratio & (Shen et al., 2004) \\
\hline Diabetic Akita mouse, heart & $\begin{array}{l}\downarrow \text { Respiration (glutamate, pyruvate), } \downarrow \text { enzymatic activity of Complex } \\
\text { V, } \downarrow \text { mRNA level (oxidative phosphorylation, antioxidant defense), } \uparrow \\
\text { UCP3 }\end{array}$ & $\begin{array}{l}\text { (Bugger et al., 2008; } \\
\text { Bugger et al., 2009) }\end{array}$ \\
\hline STZ-rat, kidney & $\begin{array}{l}\downarrow \text { Enzymatic activity of Complex I, III, and IV } \uparrow \text { membrane potential, } \\
\text { pyruvate content, Complex V activity }\end{array}$ & $\begin{array}{l}\text { (de Cavanagh et al., 2008; } \\
\text { Munusamy et al., 2009) }\end{array}$ \\
\hline \multicolumn{3}{|l|}{ Type 2 diabetes } \\
\hline $\begin{array}{l}\text { Diabetic patients, skeletal muscle } \\
\text { biopsy }\end{array}$ & $\begin{array}{l}\downarrow \text { Respiratory rate at state } 3 \text {, uncoupled respiration, respiratory } \\
\text { control index } \\
\downarrow \text { Enzymatic activity of Complex I, V and CS } \\
\downarrow \text { Size of skeletal muscle mitochondria }\end{array}$ & $\begin{array}{l}\text { (Abdul-Ghani et al., 2009; } \\
\text { Boushel et al., 2007; Kelley } \\
\text { et al., 2002; Mogensen et } \\
\text { al., 2007; Phielix et al., } \\
\text { 2008) }\end{array}$ \\
\hline $\begin{array}{l}\text { Diabetic patients, skeletal muscle } \\
\text { biopsy }\end{array}$ & $\begin{array}{l}\downarrow \text { Respiration with substrates for Complex I (pyruvate, malate, } \\
\text { glutamate) and for Complex II (succinate), no significant difference } \\
\text { when normalized to CS activity }\end{array}$ & $\begin{array}{l}\text { (Rabol et al., 2009a, b; } \\
\text { Rabol et al., 2009c) }\end{array}$ \\
\hline $\begin{array}{l}\text { Diabetic Goto-Kakizaki rats, skeletal } \\
\text { muscle }\end{array}$ & $\begin{array}{l}\downarrow \text { Enzymatic activity and protein expression of Complex I and II, mt- } \\
\text { DNA }\end{array}$ & (Shen et al., 2008) \\
\hline $\begin{array}{l}\text { Zucker diabetic fatty rats, skeletal } \\
\text { muscle }\end{array}$ & $\begin{array}{l}\downarrow \text { Enzymatic activity of Complex IV and CS normal skeletal muscle } \\
\text { mitochondrial oxidative capacity, }{ }^{31} \mathrm{P} \text { magnetic resonance } \\
\text { spectroscopy }\end{array}$ & (De Feyter et al., 2008) \\
\hline
\end{tabular}


TABLE 2

Effect of diabetes and insulin therapy on representative proteins annotated to mitochondria.

\begin{tabular}{|c|c|c|c|c|}
\hline Symbol & Protein description & Relative to control & $\begin{array}{l}\text { Relative to } \\
\text { Insulin treated }\end{array}$ & $\begin{array}{l}\% \text { of change of } \\
\text { insulin treated } \\
\text { vs. diabetic }\end{array}$ \\
\hline \multicolumn{5}{|c|}{ Complex I } \\
\hline Ndufs3 & NADH dehydrogenase (ubiquinone) Fe-S protein 3 & 0.64 & 0.84 & 131 \\
\hline Ndufv1 & NADH dehydrogenase (Ubiquinone) flavoprotein 1 & 1.13 & 0.82 & 73 \\
\hline Ndufa10 & $\begin{array}{l}\text { NADH dehydrogenase [ubiquinone] } 1 \text { alpha subcomplex subunit } \\
10\end{array}$ & 0.73 & 0.79 & 108 \\
\hline Ndufv2 & NADH dehydrogenase [ubiquinone] flavoprotein 2 & 0.91 & 0.88 & 97 \\
\hline Ndufs2 & NADH dehydrogenase [ubiquinone] iron-sulfur protein 2 & 0.48 & 0.54 & 113 \\
\hline Ndufs1 & NADH-ubiquinone oxidoreductase $75 \mathrm{kDa}$ subunit & 0.78 & 0.91 & 117 \\
\hline $\mathrm{Nd} 4$ & NADH dehydrogenase subunit 4 & 0.43 & 0.56 & 130 \\
\hline Ndufa9 & Ndufa9 protein & 0.87 & 1.19 & 137 \\
\hline Ndufs8 & Ndufs8 protein & 0.91 & 1.34 & 147 \\
\hline \multicolumn{5}{|c|}{ Complex II } \\
\hline Sdha & Succinate dehydrogenase [ubiquinone] flavoprotein subunit & 1.10 & 1.14 & 104 \\
\hline Sdhb & Succinate dehydrogenase [ubiquinone] iron-sulfur subunit & 1.11 & 1.15 & 104 \\
\hline \multicolumn{5}{|c|}{ Complex III } \\
\hline Uqcrc1 & Cytochrome b-c1 complex subunit 1 & 0.87 & 1.26 & 145 \\
\hline Uqcrc2 & Cytochrome b-c1 complex subunit 2 & 0.90 & 1.18 & 131 \\
\hline Uqcrfs1 & Cytochrome b-c1 complex subunit Rieske & 0.87 & 1.10 & 126 \\
\hline \multicolumn{5}{|c|}{ Complex IV } \\
\hline Cox4i1 & Cytochrome c oxidase subunit 4 isoform 1 & 0.71 & 0.89 & 125 \\
\hline Cox $5 \mathrm{a}$ & Cytochrome c oxidase subunit $5 \mathrm{~A}$ & 0.83 & 1.28 & 154 \\
\hline $\mathrm{COX} 2$ & cytochrome c oxidase subunit II & 0.82 & 1.06 & 129 \\
\hline \multicolumn{5}{|c|}{ Complex V } \\
\hline Atp5c1 & ATP synthase gamma chain & 0.90 & 1.29 & 143 \\
\hline Atp5a1 & ATP synthase subunit alpha & 0.89 & 1.19 & 134 \\
\hline Atp5f1 & ATP synthase subunit $b$ & 0.92 & 1.31 & 142 \\
\hline Atp5b & ATP synthase subunit beta & 0.90 & 1.10 & 122 \\
\hline Atp5jd & ATP synthase subunit $d$ & 0.86 & 1.21 & 141 \\
\hline Atp5d & ATP synthase subunit delta & 0.69 & 0.92 & 133 \\
\hline Atp5i & ATP synthase subunit e & 0.75 & 0.81 & 108 \\
\hline Atp5o & ATP synthase subunit $O$ & 0.88 & 1.13 & 128 \\
\hline Atp51 & $\begin{array}{l}\text { ATP synthase, } \mathrm{H}+\text { transporting, mitochondrial F0 complex, } \\
\text { subunit G }\end{array}$ & 0.92 & 0.85 & 92 \\
\hline \multicolumn{5}{|l|}{ TCA } \\
\hline Cs & Citrate synthase & 0.92 & 1.11 & 121 \\
\hline Aco2 & Aconitate hydratase & 0.98 & 1.11 & 113 \\
\hline Idh2 & Isocitrate dehydrogenase [NADP] & 0.96 & 1.25 & 130 \\
\hline
\end{tabular}




\begin{tabular}{|l|l|c|c|c|}
\hline Symbol & Protein description & Relative to control & $\begin{array}{c}\text { Relative to } \\
\text { Insulin treated }\end{array}$ & $\begin{array}{c}\text { \% of change of } \\
\text { insulin treated } \\
\text { vs. diabetic }\end{array}$ \\
\hline Idh3a & Isocitrate dehydrogenase [NAD] subunit alpha & 0.89 & 1.03 & 116 \\
\hline Idh3B & Isocitrate dehydrogenase [NAD] subunit beta & 0.87 & 1.49 & 171 \\
\hline Fh1 & Fumarate hydratase 1 & 0.55 & 1.19 & 216 \\
\hline Mdh2 & Malate dehydrogenase & 0.92 & 1.10 & 120 \\
\hline Ogdh & 2-oxoglutarate (a-ketoglutarate) dehydrogenase E1 component & 0.87 & 1.09 & 125 \\
\hline
\end{tabular}

Oxidative stress related

\begin{tabular}{|l|l|c|c|r}
\hline Sod2 & Superoxide dismutase $[\mathrm{Mn}]$ & 0.73 & 1.08 & 148 \\
\hline Aldh2 & Aldehyde dehydrogenase & 0.98 & 1.19 & 121 \\
\hline Prdx3 & Peroxiredoxin-3 & 0.87 & 1.26 & 146 \\
\hline Prdx5 & Peroxiredoxin-5 & 0.74 & 0.86 & 116 \\
\hline
\end{tabular}

Heat shock proteins

\begin{tabular}{|l|l|l|l|c|}
\hline Hspe1 & $10 \mathrm{kDa}$ heat shock protein & 0.96 & 0.94 & 98 \\
\hline Hsp60 & 60 kDa heat shock protein & 0.93 & 0.98 & 105 \\
\hline Hsp90aa1 & HSP 90-alpha & 0.79 & 1.32 & 167 \\
\hline Hsp90ab1 & HSP 90-beta & 0.83 & 1.37 & 165 \\
\hline
\end{tabular}

Fatty acid utilization

\begin{tabular}{|c|c|c|c|c|}
\hline Cpt1a & Carnitine O-palmitoyltransferase 1 , liver isoform & 0.51 & 0.77 & 151 \\
\hline Acat1 & Acetyl-CoA acetyltransferase & 0.74 & 1.01 & 136 \\
\hline Acaa1a & acetyl-Coenzyme A acyltransferase 1 & 0.81 & 1.3 & 160 \\
\hline Echs1 & Enoyl-CoA hydratase & 0.80 & 1.18 & 148 \\
\hline Hadh & Hydroxyacyl-coenzyme A dehydrogenase & 0.93 & 1.14 & 123 \\
\hline Hsd17b10 & Hydroxysteroid (17-beta) dehydrogenase 10 & 0.71 & 1.14 & 161 \\
\hline Acadl & Long-chain specific acyl-CoA dehydrogenase & 1.00 & 0.99 & 99 \\
\hline Acadm & Medium-chain specific acyl-CoA dehydrogenase & 0.91 & 1.19 & 131 \\
\hline Acadvl & Very long-chain specific acyl-CoA dehydrogenase & 0.82 & 1.04 & 127 \\
\hline Hadha & Trifunctional enzyme subunit alpha & 0.89 & 1.10 & 124 \\
\hline Hadhb & Trifunctional enzyme subunit beta & 0.82 & 1.04 & 127 \\
\hline \multicolumn{5}{|c|}{ Other proteins } \\
\hline Cyb5b & Cytochrome b5 type B & 0.71 & 0.97 & 137 \\
\hline Ant1 & ADP/ATP translocase 1 & 0.84 & 1.15 & 137 \\
\hline Ant2 & ADP/ATP translocase 2 & 0.87 & 1.22 & 140 \\
\hline Ckmt & Creatine kinase & 1.52 & 0.80 & 53 \\
\hline Cycs & Cytochrome c, somatic & 0.56 & 0.90 & 161 \\
\hline Cyc1 & cytochrome c-1 & 0.85 & 1.11 & 131 \\
\hline Glud1 & Glutamate dehydrogenase 1 & 0.90 & 1.08 & 120 \\
\hline Gpd2 & Glycerol-3-phosphate dehydrogenase & 0.83 & 1.16 & 140 \\
\hline Hk1 & Hexokinase-1 & 0.74 & 0.93 & 126 \\
\hline Ldha & L-lactate dehydrogenase A chain & 1.13 & 1.86 & 165 \\
\hline
\end{tabular}




\begin{tabular}{|l|l|c|c|c|}
\hline Symbol & Protein description & Relative to control & $\begin{array}{c}\text { Relative to } \\
\text { Insulin treated }\end{array}$ & $\begin{array}{c}\text { \% of change of } \\
\text { insulin treated } \\
\text { vs. diabetic }\end{array}$ \\
\hline Fis1 & Fis1 protein & 0.59 & 0.97 & 164 \\
\hline Tomm70a & Mitochondrial import receptor subunit TOM70 & 1.06 & 0.65 & 61 \\
\hline
\end{tabular}

Table 2 represents a summary of our own mass spectrometry data of protein expression related to mitochondria and affected by diabetes and its correction by insulin therapy. Changes in percent represent the effect of insulin treatment on the protein expression ratio measured from diabetic rats. Copyright 2011 American Diabetes Association. From Diabetes, vol. 60, 2011; 291. Reprinted with permission from the American Diabetes Association. 